\title{
STUDYING THE EFFECT OF POLYVINYLPYRROLIDONE (PVP) ON CHARACTERIZATION OF ZNO NANOPARTICLES SYNTHESIZED BY SOL - GEL METHOD.
}

\author{
Shaima'a Jaber Kareem \\ shaimaa.j.kareem@gmail.com \\ University of Babylon Engineering Materials College \\ Department of Ceramic Engineering and Building Materials.
}

\begin{abstract}
In this paper, studying synthesis zinc oxide nanoparticles ( $\mathrm{ZnO} \mathrm{NPs}$ ) via sol - gel method and effect of adding polymer in preparation its solution. Zinc nitrate hexahydrate, Polyvinylpyrrolidone PVP, distilled water and sodium hydroxide $(\mathrm{NaOH})$ were used as precursor materials. Crystallization behavior of the $\mathrm{ZnO}$ was studied by X-ray diffraction (XRD). Nanoparticles phases can change from amorphous to wurtzite structure at the calcination temperature $\left(500{ }^{\circ} \mathrm{C}\right)$ and crystallite size by Scherrer's formula about $(21.131)$ $\mathrm{nm}$ for samples prepared with distilled water and (20.035)nm for samples prepared with dissolved PVP. Morphological and structural properties were investigated by scanning electron microscopy (SEM). FT-IR spectra was indicated characteristic absorption bands of $\mathrm{ZnO}$. UV-Vis absorption spectrum was shown a typical spectrum for $\mathrm{ZnO}$ nanoparticles. Finally, the results were shown the samples with dissolved PVP has smaller particles size, less agglomeration and narrow distribution but less purity phase when compared with samples prepared with distilled water.
\end{abstract}

KEY WORDS: Nanoparticles, ZnO, sol- gel, PVP, FE-SEM, XRD, UV, FTIR

$$
\begin{aligned}
& \text { دراسة تأثير بولي فينل بيروليدون(PVP) على خواص جسيمات لأوكسيد الزنك (ZnO) } \\
& \text { النانوية المحضر بطريقة السول - جل. } \\
& \text { شيماء جابر كريم } \\
& \text { جامعة بابل / كلية هندة المواد/ قسم السيراميك ومواد البناء }
\end{aligned}
$$

في هذا البحث نم تحضير جسيمات نانوية من أوكسيد الزنك (ZnO) بطريقة الهلام ودراسة تأثير إضافة بوليمر في محلول التحضير. نترات الزنك المائية، وبوليمر متعدد فينل بيروليدون(PVP)، ماء مقطر، هيدروكسيد

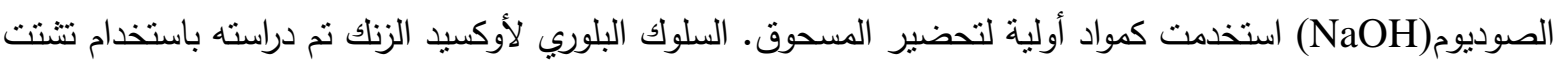

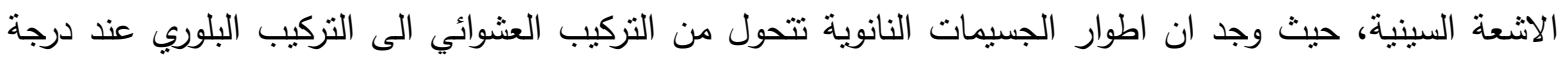
حرارة الكلسنة 500 درجة مئوية اما حجم البلورة فتم حسابها بواسطة معادلة شيرر Scherrer's formula وكان حوالي سلي

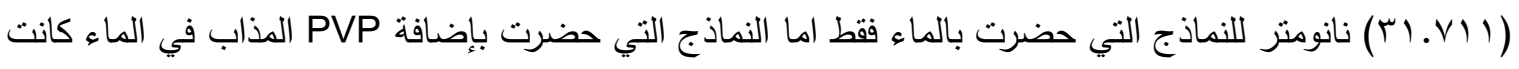




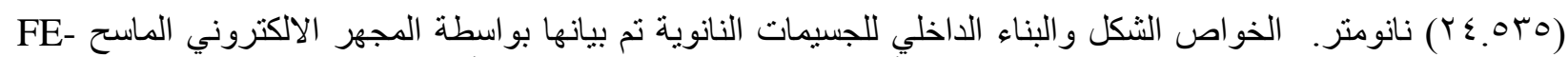

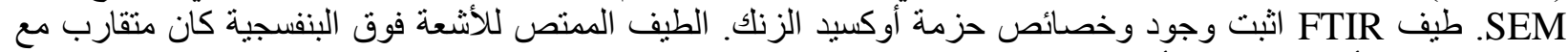

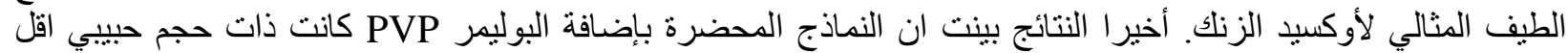

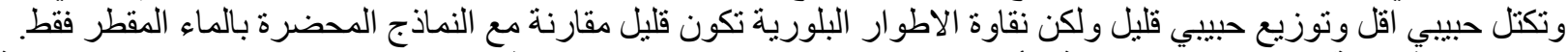

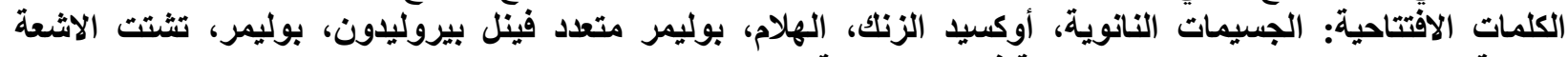

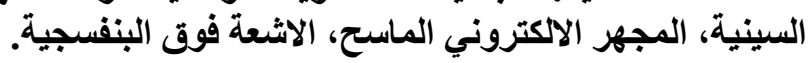

\section{INTRODUCTION}

Crystalline of Zinc oxide has a "wurtzite structure", which from the "space group $\mathrm{P}^{3} \mathrm{mc}$ ". In the $\mathrm{ZnO}$, hexagonal structure each ion of $\mathrm{Zn}^{2+}$ is tetrahedral connected to four $\mathrm{O}^{2-}$ ions in lattice and vice-versa. Zinc oxide exhibits both covalent and ionic compound because of the tetrahedral coordination of $\mathrm{ZnO}$ indicates the presence covalent bonds, and the strong $\mathrm{Zn}-\mathrm{O}$ ionic character. The hexagonal unit cell of $\mathrm{ZnO}$ has lattice parameters: $\mathrm{a}=3.2495 \AA$ and $\mathrm{c}=5.2069 \AA$ [Chennupati J., et al, 2007].

In materials science, zinc oxide is the one of the most important $\mathrm{n}$ - type semiconductor materials [Agnieszka K., \& Teofil J., 2014],[Mohammad V., 2010].

Zinc oxide has important attention because of the unique characterizations of morphology and dimension dependent optoelectronic. $\mathrm{ZnO}$ has featured properties: thermodynamic and electrodynamics properties, high chemical activity, and remarkable optical, mechanical, electromagnetic, which exhibit a wide spectrum of application: gaseous sensors, photo catalysts, fluorescent materials, and additives in many industrial products. Zinc oxide is an environmentally friendly material, so is suitable for bio application, as cancer detection and bio imaging. Various physical and chemical processes develop to get $\mathrm{ZnO}$ particles in micro or nano scale with different shapes. [Munusamy Th., et al, 2013].

Now days, different routs have used for preparation of $\mathrm{ZnO}$ nanoparticles, such as sol - gel, hydrothermal / solvothermal, micro emulsion, colloidal, rietveld method, precipitation, and physical vapor deposition methods [Agnieszka K., et al, 2014][Tatyana G. et al, 2014][Tagreed M. Al- Saadi, et al, 2014][Harish K., Renu R., 2013]. Nano powders have prepared by sol- gel process had good homogenous, high purity, and high quality. The nanoparticles morphology have depended on the type of the solvent. [T.V. Kolekar, et al, 2011].

There are many research studies of preparation of $\mathrm{ZnO}$ by using sol - gel method including:

T.V. Kolekar, et al [2011] have prepared nanoparticles of $\mathrm{ZnO}$ at room temperature. Starting materials used were zinc acetate and triton X-100. After stirred the solution for 1hour slightly precipitation noted by added $\mathrm{NaOH}$ to complete precipitation, than the powder calcined at $673^{\circ} \mathrm{K}$. The average particle size of nanoparticles $\mathrm{ZnO}$ about (10nm).

Robina A., et al [2013] have prepared nanoparticles of $\mathrm{ZnO}$ with particle size less than 50nm. These nanoparticles can be used in hetero junction organic solar cells. A precursor material used zinc acetate. The results was shown that $\mathrm{ZnO}$ has wurtzite structure with spherical particles has size less than $(100 \mathrm{~nm})$ and uniform size distribution.

Sanjeev, et al [2014] have prepared the Quantum of ZnO (QDS) by using the starting materials were zinc acetate dehydrate, methanol and sodium hydroxide. After calcination the synthesized samples at $500^{\circ} \mathrm{C}$ for 1 hour, the product had good crystallinity with the average crystalline size of the QDS $14 \mathrm{~nm}$.

S. Surablu, et al [2015] have studied synthesis the $\mathrm{ZnO}$ nano powders from an ethanol solution, zinc sulfate heptohydrate and diethylene glycol surfactant. Results show that these nanoparticles are hexagonal wuntzite in phase $\mathrm{ZnO}$ with a mean grain size of about $28 \mathrm{~nm}$. It is clear with 
increasing temperature the morphology of the particles change to the spherical shape and nano powder were less agglomerate.

Riyadh M. Alwan, et al [2015] have synthesized zinc oxide nanoparticles by using zinc acetate. The results have revealed the $\mathrm{ZnO}$ prepared had wurtzite structure with highly crystallinity, and spherical in shape with smooth surface.

S. R. Brintha and M. Ajitha, [2015] have prepared $\mathrm{ZnO}$ by various methods addition to sol- gel, the aqueous solution, and hydrothermal methods. The resulted $\mathrm{ZnO}$ particles have found in the nanometer scale about $13 \mathrm{~nm}, 14 \mathrm{~nm}$, and $18 \mathrm{~nm}$ respectively.

In the present study, a sol -gel method are used to prepare $\mathrm{ZnO}$ nano particles, using starting materials like Zinc nitrate hexahydrate, sodium hydroxide, and distill water, and Polyvinylpyrrolidone (PVP). Studying the morphology and nanostructure of the powder are largely affected by PVP.

\section{PREPARATION POWDER}

\section{Raw Materials}

The raw materials used in this study are presented in table (1).

\section{Dissolving and Mixing:}

In this study, $\mathrm{ZnO}$ nanoparticles is synthesized by sol - gel, the starting material is $\mathrm{Zn}$ $\left(\mathrm{NO}_{3}\right)_{2} \cdot 6 \mathrm{H}_{2} \mathrm{O}$ dissolved once in distilled water and second in distilled water with and adding PVP at $50{ }^{\circ} \mathrm{C}$ for $2 \mathrm{hrs}$ by using hot plate magnetic stirrer type (Stuart SB 162-3, England). To get the required $\mathrm{PH}$ can be added drop by drop of the sodium hydroxide $(\mathrm{NaOH})$ to solution. It is stirred ultrasonically for $1 \mathrm{hr}$ at room temperature due to $\mathrm{PH}$ desired. The solution are aging for $4 \mathrm{hr}$ to complete the process, and then the white $\mathrm{ZnO}$ crystalline is settled down and precipitates. That white precipitate is filtered by using filtration paper measuring 42 then washed with excess ethanol and distilled water to remove the starting materials.

\section{Drying and Calcination process:}

The drying process is carried out for $\mathrm{ZnO}$ powder at $150{ }^{\circ} \mathrm{C}$ for $5 \mathrm{~h}$ by using porcelain basin in oven dryer type (memmert Gmbh+Co.KG, universal oven (UIS), Germany). The dried $\mathrm{ZnO}$ nanoparticles are calcinated at $500{ }^{\circ} \mathrm{C} 1 \mathrm{~h}$ in air by using furnace up to $1600^{\circ} \mathrm{C}$ for pyrolysis, type (Protherm, Turky). The heating rate was kept at $5^{\circ} \mathrm{C} / \mathrm{min}$.

\section{Characterizations:}

The structure of $\mathrm{ZnO}$ the nanoparticles are studied by the X-ray diffraction (XRD) instrument, type (Shimadzo, XRD6000, diffractometer, Japan). X-rays are generated using Copper $(\mathrm{Cu}-\mathrm{K} \alpha)$ radiation at $30 \mathrm{kV}, 40 \mathrm{~mA}$ and wavelength $(\lambda=1.5406 \AA)$, radiation to generate diffraction patterns from crystalline samples of powder at ambient temperature in a $2 \theta$ range of $20^{\circ}$ to $80^{\circ}$. Fourier Transmission Infrared Spectroscopy (FTIR), type model (Iraffinity- 1Shimadzu), was used to investigate the bonds. Scanning electron microscopy (FE-SEM) are studied to investigate the microstructure of the crystals and nanoparticle size, type (MIRA3 TESCAN- RMRC) (TM 1000 Hitachi tabletop Japan). "The UV absorption measurement" was occurred in range of (200800) nm by "UV-Visible spectrophotometer", model UV- 1800 shimadzu.

\section{- RUSTLES AND DISCUSSION:}

\section{XRD Analysis:}

Generally, XRD can be used to study the morphology and crystallinity of particles. Fig. (1) shows XRD patterns of zinc oxide powder samples after being calcined at $500{ }^{\circ} \mathrm{C}$ for 1 hour, 
comparing with standard JCDPS card. The d values and intensities of observed diffraction peaks matches well with JCPDS card (00-036-1451). The peaks are indexed as "31.78 (100), 34.43 (002), 36.29 $(101), 47.54^{\circ}(102), 56.59^{\circ}(110), 62.85^{\circ}(103), 66.36^{\circ}(200), 67.95^{\circ}(112), 69.07^{\circ}$ (201) and $76.966^{\circ}(202)^{\prime \prime}$ respectively for $\mathrm{ZnO}$ prepared in distilled water. The peaks are indexed as "31.91 ${ }^{\circ}(100), 34.56^{\circ}(002), 36.39^{\circ}(101), 47.67^{\circ}(102), 56.71^{\circ}(110), 62.97^{\circ}(103), 66.47^{\circ}$ (200), $68.05^{\circ}(112), 69.20^{\circ}(201)$ and $77.09^{\circ}(202)^{\prime \prime}$ respectively for $\mathrm{ZnO}$ prepared in distilled water with added PVP. XRD diffraction pattern was exhibited no impurities due to absent any foreign peak. This proves that synthesized nanoparticles of $\mathrm{ZnO}$ was highly purity but there were forgone peaks shown in chart for $\mathrm{ZnO}$ prepared in distilled water with added PVP may be found reaction between $\mathrm{ZnO}$ and PVP that agree with a FTIR measurement.

The crystallite size of nanoparticles for structural limitation and evaluation of crystallite size by using Scherrer's formula at the peak (101):

$$
\mathrm{D}_{\mathrm{XRD}}=0.89 \lambda / \beta \cos \theta
$$

Where $\lambda$ is" wavelength of X-ray radiation used in $\AA$ ", $\theta$ is" the diffraction angle", $\beta$ is "the full width at half maximum (FWHM) in radians in the $2 \theta$ scale", $D_{\text {XRD }}$ is "the crystallite size in nm". [Cullity, 1967].

The lattice constants $(\mathrm{a}, \mathrm{c})$ of the synthesized nanoparticles, according to the hexagonal crystal wurtzite structure was determined from the main peak of wurtzite structure $(1+1)$ by using cellacalc program which depending on the interplanar distance, $\mathrm{h}, \mathrm{k}$ and 1 (the miller indices). The decreasing in average crystalline size and lattice constant may be due to add PVP to dissolved solution. The structural parameters calculated from the diffraction pattern shown in Table 2.

\section{Field Emission Scanning Electron Microscopy (FE-SEM) analysis:}

The surface morphology of synthesized nanoparticles was studied by FE- SEM, from this technique can be determine the grain size of $\mathrm{ZnO}$ nanoparticles. Fig. (2) was explained the FESEM images for samples calcined at $500{ }^{\circ} \mathrm{C}$. From Fig. (2-a) FE- SEM image is shown the grain size about (26.62-39.20) $\mathrm{nm}$ for $\mathrm{ZnO}$ prepared in distilled water, while Fig. (2-b)FE- SEM image is shown the $\mathrm{ZnO}$ nanoparticles formed were less agglomerated and grain size about (21.4932.90) $\mathrm{nm}$ for $\mathrm{ZnO}$ prepared in distilled water with adding PVP. The FE- SEM images were shown the homogeneity of microstructural of $\mathrm{ZnO}$ nanoparticles.

\section{Fourier transform infrared spectroscopy (FTIR):-}

FTIR measurement was carried out in order to confirm the bond structure of $\mathrm{ZnO}$ nanoparticles. FTIR spectrum of $\mathrm{ZnO}$ nanoparticles, which prepared with water and with added PVP. Figure (3.3) was shown considerable absorption peaks at $3489.23 \mathrm{~cm}^{-1}, 1575.84 \mathrm{~cm}^{-1}$, and $45502 \mathrm{~cm}^{-1}$ that band are specified to stretching vibrations of $\mathrm{Zn}-\mathrm{O}$ in two samples with water and with added PVP, which was described in [R.Y.Hong et al, 2009]. The wide absorption band at $3057.17 \mathrm{~cm}^{-1}$ was due to stretching vibrations of $\mathrm{O}-\mathrm{H}$ bond to adsorbed water at the particles surface. An absorption peak at $1375.25 \mathrm{~cm}^{-1}$ is specified to the $\mathrm{C}=\mathrm{O}$ stretching vibration. Peaks at $1489.05 \mathrm{~cm}^{-1}$ and $852.54 \mathrm{~cm}^{-1}$ are assigned to the $\mathrm{C}-\mathrm{H}$ in PVP solution as accepted with [Tatyana G., et al 2014].

The peaks of samples which prepared with added PVP are stretched and deformed because of that chemical reaction was happened between nanoparticles of $\mathrm{ZnO}$ and polymer, by coordination of the $\mathrm{ZnO}$ nanoparticles with the PVP by hydrogen and oxygen atoms, as evidenced in [Ilegbusi O.J. and L.I. Trakhtenberg, 2013] [Tatyana G., et al 2014]. These results are shown shifting in band due to calcination temperature, that samples are needed higher 
calcination temperature than $500{ }^{\circ} \mathrm{C}$ in order to remove secondary compounds and reduced the shifting of peaks.

\section{UV-visible Absorption:}

Fig (4) was shown the absorbance and wavelength from in the range (200 to 800) $\mathrm{nm}$ the UV-Vis spectra of $\mathrm{ZnO}$ nanoparticles. The absorbance at wavelength, which because of the small particles size effect on quantum confinement. A clearly shift at blue light wavelength was absorbed. A sharp peak of UV emission was centered about $365 \mathrm{~nm}$, this was indicated a blue shift in the spectrum. The peak of exciting absorption was observed because of $\mathrm{ZnO}$ nanoparticles found below the wavelength of band gap of bulk zinc oxide $(388 \mathrm{~nm})$ and was represented mono dispersion of nanoparticles, which was referred for almost uniform nanoparticles size. A slight shift in the absorption peaks was observed while upon change in size or shape particles, as evidenced in [Guo L, et al, 2001] [Riyadh M. Alwan et al, 2015]. The band of UV emission was cleared by the transition of near band-edge of the board band gap zinc oxide nanoparticles, which referred to the defects like vacancies of oxygen ions and interstitials of $\mathrm{Zn}$ ions [Xu LF, et al, 2005]. From these figures, the $\mathrm{ZnO}$ nanoparticles that prepared with added PVP to dissolved solution less in shifting due no aggregation and agglomeration and small particle size as found in XRD analyses and SEM image.

\section{CONCLUSIONS}

The zinc oxide $\mathrm{ZnO}$ nanoparticles have been prepared via the sol-gel process at low calcinations temperatures $\left(500^{\circ} \mathrm{C}\right)$ with a cubic wurtzite structure. This work focused on the effects for added PVP dissolved in water in the preparation of $\mathrm{ZnO}$ nanoparticles via sol-gel process and their effect on the variation of properties. The prepared $\mathrm{ZnO}$ nanoparticles were characterized using XRD, FE-SEM, FTIR and UV-Vis measurements. The average particle size was found $21.49 \mathrm{~nm}$ for samples with added PVP dissolved in water, low agglomeration and narrow distribution but less purity phase when compared with samples prepared with distilled water, which had $26.62 \mathrm{~nm}$.

Table (1) the raw materials used.

\begin{tabular}{|l|c|c|c|c|}
\hline \multicolumn{1}{|c|}{ Raw materials } & Formulation & $\begin{array}{c}\text { Molecular } \\
\text { weight }(\mathrm{g} / \mathrm{mol})\end{array}$ & Purity \% & $\begin{array}{c}\text { Physical } \\
\text { state }\end{array}$ \\
\hline $\begin{array}{l}\text { Zinc nitrate } \\
\text { hexahydrate }\end{array}$ & $\mathrm{Zn}\left(\mathrm{NO}_{3}\right)_{2} \cdot 6 \mathrm{H}_{2} \mathrm{O}$ & 297.4815 & 99 & Solid \\
\hline Sodium Hydroxide & $\mathrm{NaOH}$ & & & Solid \\
\hline Distilled Water & $\mathrm{H}_{2} \mathrm{O}$ & 1 & & Liquid \\
\hline Polyvinylpyrrolidone & $\left(\mathrm{C}_{6} \mathrm{H}_{9} \mathrm{NO}\right)_{\mathbf{n}}$ & $\mathbf{3 0 0 0 0}$ & $\mathbf{9 9 . 9}$ & Solid \\
\hline
\end{tabular}

Table (2) Structural parameters of $\mathrm{ZnO}$ calcinated at $500^{\circ} \mathrm{C}$.

\begin{tabular}{|c|c|c|c|}
\hline ZnO & $\mathbf{D}_{\text {XRD }}(\mathrm{nm})$ & $\mathbf{a}(\AA)$ & $\mathrm{c}(\AA)$ \\
\hline With water & 21.131 & 3.24892 & 5.20062 \\
\hline With added PVP & 20.035 & 3.23653 & 5.18627 \\
\hline
\end{tabular}



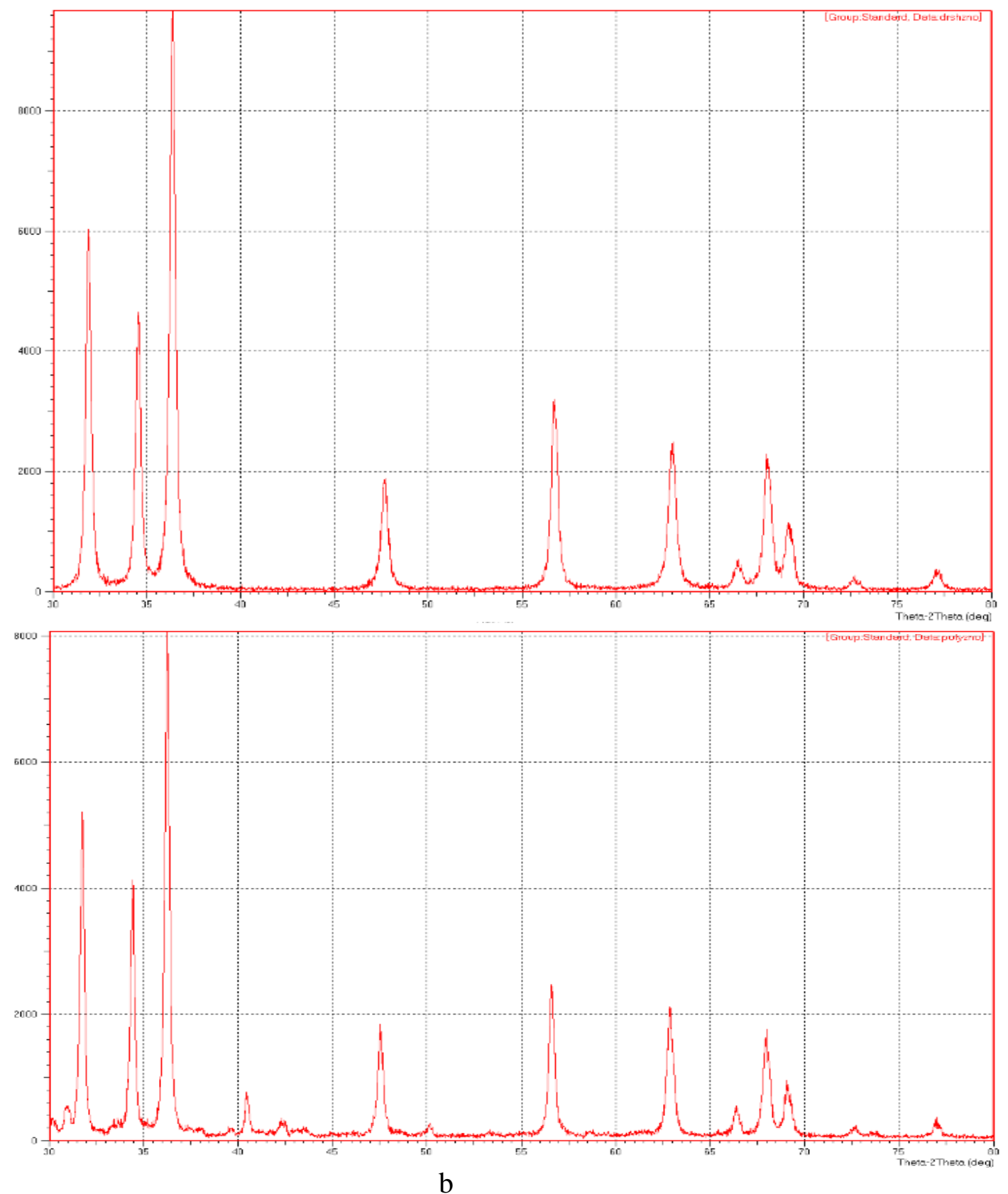

Figure (1): XRD patterns of zinc oxide calcinated at $500{ }^{\circ} \mathrm{C}$ samples: a- with water to dissolved solution, b- With added PVP to dissolved solution 

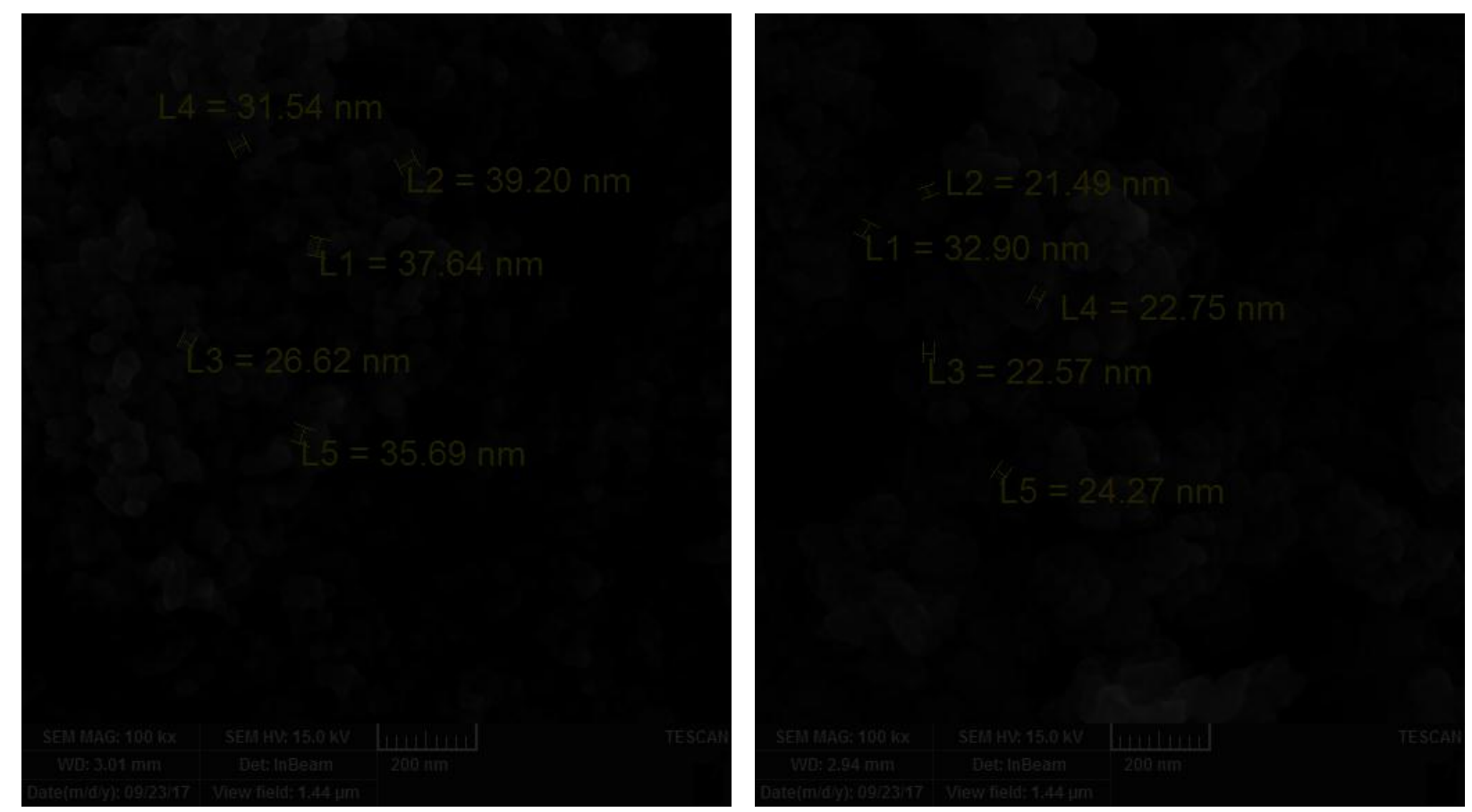

a

$\mathrm{b}$

Fig. (2): SEM of zinc oxide calcinated at $500{ }^{\circ} \mathrm{C}$ samples: a- with water dissolved solution, b- With added PVP to dissolved solution.

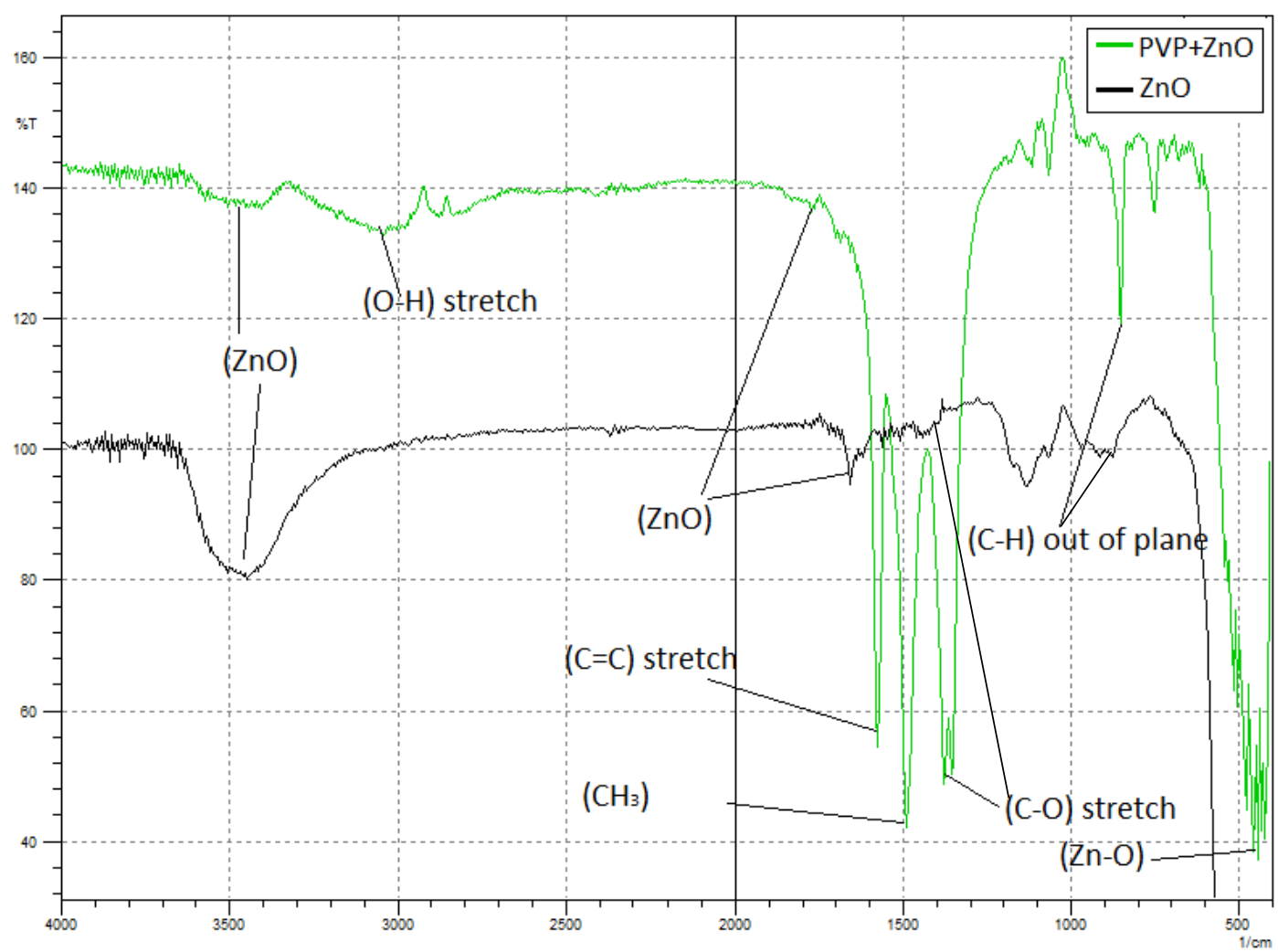

Figure (3) The FTIR spectra of $\mathrm{ZnO}$ samples with water and 
with added PVP to dissolved solution

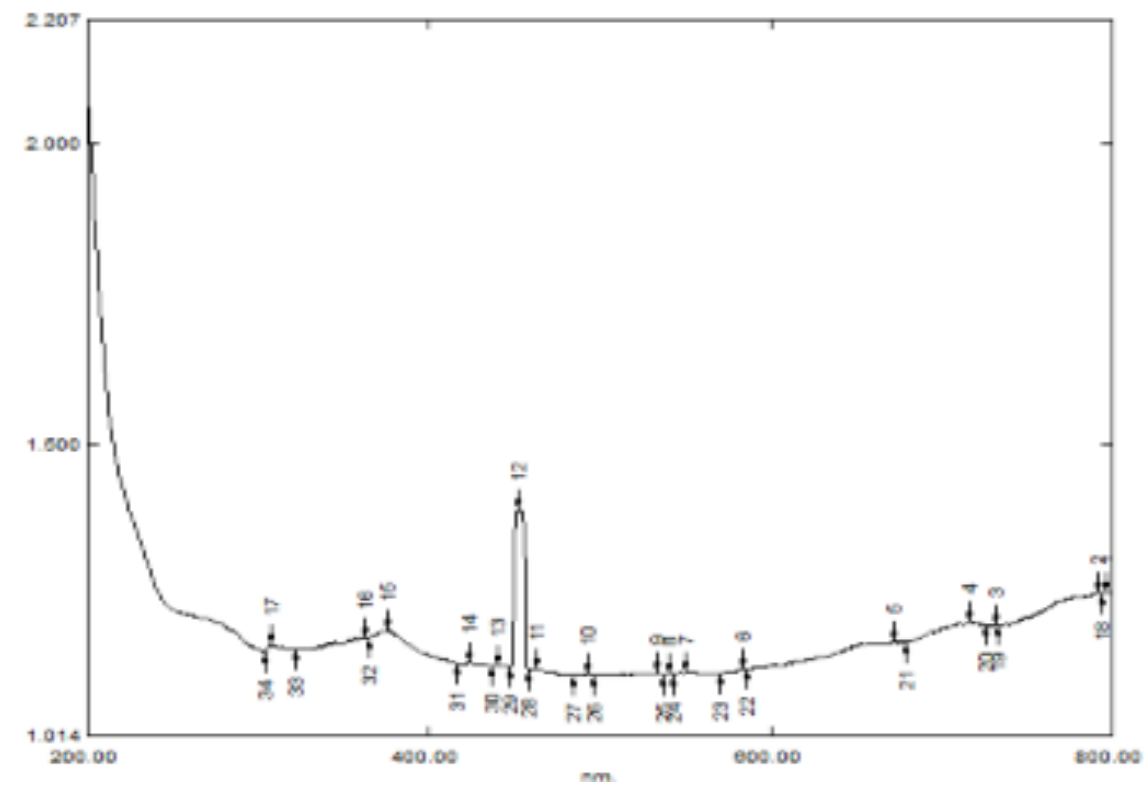

$a$

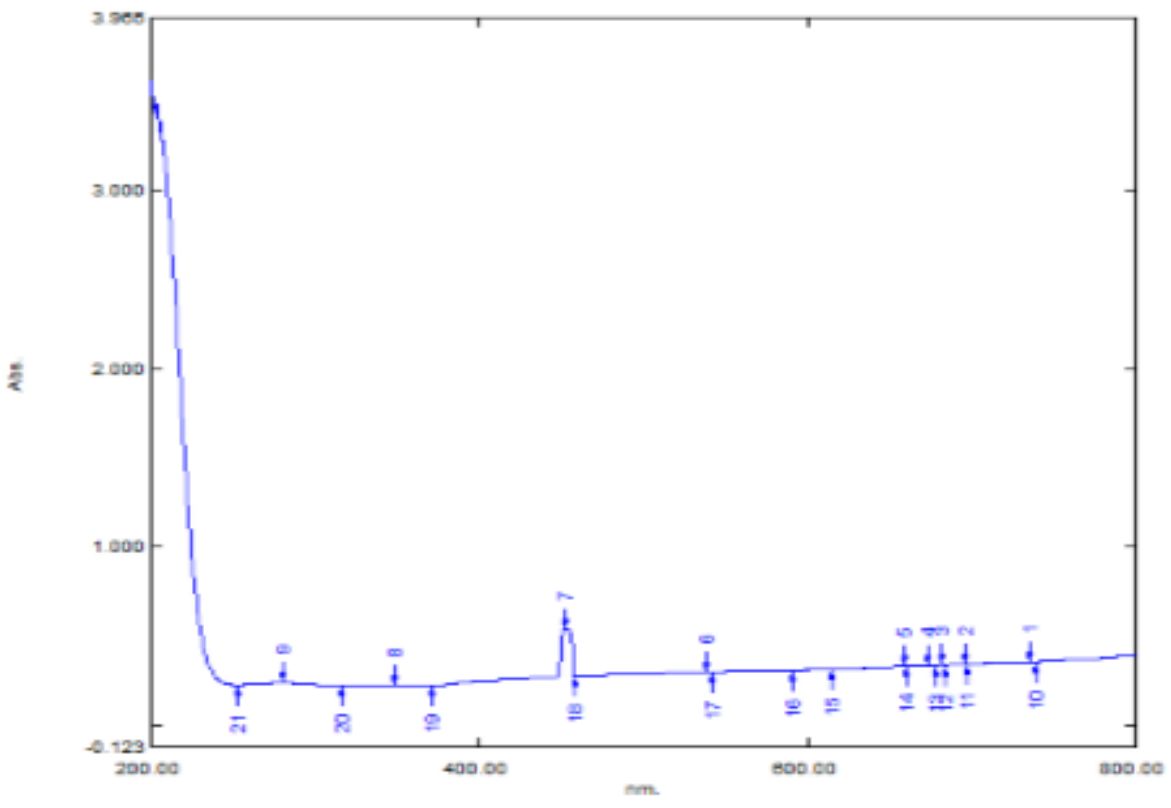

b

Figure (4): Absorption of $\mathrm{ZnO}$ nanoparticles as a function of wavelength a- with water to dissolved solution, b- With added PVP to dissolved solution 


\section{REFERANCES:}

Agniesh K.R., Teofil J., 2014," Zinc Oxide- from Synthesis to Application: A Review", Mterials, Vol. 7, pp.2833-2881.

Chennupati J. \& Stephen J. P, 2007, "Zinc oxide Bulk, Thin Films and Nanostructures", China: Elsevier.

Cullity, B. D., 1967, Elements of X-ray Diffraction, London, Adison-Wesley Publ. Co.,

Guo L., Cheng X. Y., Yan Y. J. and Ge W. K., 2001, "Synthesis and optical properties of crystalline polymer-capped $\mathrm{ZnO}$ Nanorods", Materials science and engineering, Vol.16, pp. 123-127.

Harish K., Renu R., 2013, "Structural and Optical Characterization of ZnO Nanoparticles Synthesized by Microemulsion Route", International Letters of Chemistry, Physics and Astronomy, Vol. 14, pp. 26-36.

Ilegbusi O.J. and L.I. Trakhtenberg, 2013, "Synthesis and Conductometric Property of Sol-GelDerived ZnO/PVP Nano Hybrid Films", Journal of Materials Engineering and Performance, Vol.22, pp.911-915.

Mohammed V., Ahmed U., Yoon - Bong H., 2010, " Properties and Application: Metal oxide nanostructure and their Application", American Scientific Publishers, Vol.5, pp.1-36.

Munusamy Th., Kai-Lin H., Jiunn-Fwu L., 2013, "Preparation and Morphology Studies of Nano Zinc Oxide Obtained Using Native and Modified Chitosans", Materials, Vol.6, pp.4198-4212.

R.Y. Hong, J.H. Li , L.L. Chen, D.Q. Liu , H.Z. Li , Y. Zheng, J. Ding, 2009, " Synthesis, surface modification and photocatalytic property of $\mathrm{ZnO}$ nanoparticles", Powder Technology, Elsevier, Vol. 189, pp. 426-432.

Riyadh M. A., Quraish A. K., Kassim M. S., Rawaa A. A., Roaa J. M., Noor A. K., Alwan N. J., 2015, " Synthesis of Zinc Oxide Nanoparticles via Sol - Gel Route and Their Characterization", Nanoscience and Nanotechnology, Vol. 5, No.1, pp.: 1-6.

Robina A., Saira R., Muhammad Kh.R., Shahzad N., 2013, "Synthesis and Characterization of $\mathrm{ZnO}$ Nanoparticles", The word congress on advances in Nano, Biomechanics,Robtics, and Energy Research, Seoul.Korea,pp.288-296.

S. Jurablu, M. Farahmandjou, T. P. Firoozabadi, 2015, " Sol-Gel Synthesis of Zinc Oxide (ZnO) Nanoparticles: Study of Structural and Optical Properties", Journal of Sciences, Islamic Republic of Iran, Vol. 26, No. 3, pp. $281-285$.

S.R.Brintha, M.Ajitha, 2015, "Synthesis and characterization of $\mathrm{ZnO}$ nanoparticles via aqueous solution, sol-gel and hydrothermal methods", IOSR Journal of Applied Chemistry, Vol. 8, pp. 66-72. 
Sanjeev K., Fouran S., A. Kapoor, 2014, "Synthesis and Characterization of Nano-Crystalline ZnO Quantum Dots via Sol-Gel Route for Dye-Sensitized Solar Cells", International Journal of Recent Trends in Electrical \& Electronics Eng., Vol. 4, pp.: 25-29.

T.V.Kolekar, H.M.Yadav, S.S.Bandgar, A.C.Raskar, S.G.Rawal, G.M.Mishra, 2011, "Synthesis by Sol-gel Method and Characterization of ZnO Nanoparticles", Indian Streams Research Journal, Vol.1.

Tagreed. M. S., Nabeel A. B., Noor A. H., 2014, " Study of nanocrystalline structure and micro properties of $\mathrm{ZnO}$ powders by using Rietveld method", International Journal of Engineering and Technical Research, Vol.2, pp.191-195.

Tatyana G., Emil R., Nadejda C., Veaceslav U.,Evgenii G., Paulina V., 2014, " Preparation of poly(N-vinylpyrrolidone)-stabilized ZnO colloid nanoparticles", Beilstein Journal Nanotechnol, Vol.5,pp. 402-406.

Xu LF, Guo Y, Liao Q, Zhang JP, Xu DS, 2005, "Morphological control of ZnO nanostructures by electrodeposition", J Phys Chem B, Vol.109, No.28, pp:13519-13522. 